九州大学学術情報リポジトリ

Kyushu University Institutional Repository

\title{
Development of a Prediction Model for NVOC Concentration with Changing Microclimate in Camellia Japonica Temple Forest
}

\section{KIM, Geonwoo}

Forest Welfare Division, Forest Policy and Economics Department, National Institute of Forest Science

PARK, Bum-Jin

Department of Environment and Forest Resources, College of Agriculture \& Life Sciences, Chungnam National University

KOGA, Shinya

Department of Agro-environmental Sciences, Faculty of Agriculture, Kyushu University

https://doi.org/10.5109/4363558

出版情報: 九州大学大学院農学研究院紀要. 66 (1)，pp.105-113，2021-03-01. Faculty of Agriculture, Kyushu University

バージョン :

権利関係 : 


\title{
Development of a Prediction Model for NVOC Concentration with Changing Microclimate in Camellia Japonica Temple Forest
}

\author{
Geonwoo KIM ${ }^{1}$, Bum-Jin PARK ${ }^{2 *}$ and Shinya KOGA \\ Laboratory of Forest Resources Management, Division of Forest Environmental Sciences \\ Department of Agro-Environmental Sciences, Faculty of Agriculture, Kyushu University, Fukuoka 811-2415, Japan \\ (Received October 29, 2020 and accepted November 4, 2020)
}

\begin{abstract}
This study aimed to make an efficient estimation of the concentration of NVOC with changing climate conditions in the forests possessed by Buddhist temple for the purpose of landscape preservation and procurement of material and operating expenses for Buddhist temple in Korea. To complement economic and technical issues of existing NVOC measurement techniques, the study conducted a total of 48 survey and analysis sessions from May 2016 to June 2016 in Camellia japonica forest, representing the climate of warm temperate zone. The comparison of the NVOC construction in Camellia japonica forest in summer showed $51 \%$ of $\alpha$-pinene $\left(1.79 \mu \mathrm{g} / \mathrm{m}^{3}\right)$, followed by $19 \%$ of $\beta$-pinene $\left(0.68 \mu \mathrm{g} / \mathrm{m}^{3}\right)$. The analysis of daily NVOC concentration showed that it was the highest during the sunrise and the concentration increased when the photo-environment changed and when there was a smaller effect of wind velocity. The study also presented a concentration prediction model with varying microclimate conditions using a multiple regression analysis. The regression analysis on the estimated concentration and the observed data demonstrated that the proposed model had a higher explanatory force at $84.5 \%$. This study offered scientific evidence which can inform the management of 'Buddhist temple forests' along with forest environment in general, helping to promote public welfare and meditation space.
\end{abstract}

Key words: Buddhist temple forest, Camellia japonica, Forest healing, NVOC, Phytoncide

\section{INTRODUCTION}

Since the outbreak of new viruses that cause highly infectious pandemics among humans, such as SARS, MERS, and 2009 H1N1 influenza epidemics, and COVID19 pandemics, people have been increasingly interested in healthy living surrounded by nature (Tollefson, 2020; Slater et al., 2020; Stanhope et al., 2020; Zabini et al., 2020). Although having comfortable lives through industrialization and urbanization, people paradoxically are both disconnected from nature and more exposed to many stressful environments. Exposure to stressful environments like noise, anxiety about accidents, effects of environmental pollution and complex lifestyle are crucially effective to human's mental and physical health. Not only that, they may cause social problems (Tafet and Bernardini., 2003; Marin et al., 2013). AVOC (Anthropogenic Volatile Organic Compound) existing within urban atmosphere have been emitted through industrial facilities, architecture materials and vehicle. Some of them in itself present either harmful toxic or carcinogenesis and mutation traits for health (WHO, 2015). With the increasing number of senior citizens and patients with chronic diseases and lifestyle diseases, there is an increasing need for spaces in nature that accommodate physical and mental stability (Kim et al., 2016). In 1982, the Ministry of Agriculture, Forestry and

\footnotetext{
Forest Welfare Division, Forest Policy and Economics Department, National Institute of Forest Science, 57 Hoegiro, Dongdaemun-gu, Seoul, Korea

2 Department of Environment and Forest Resources, College of Agriculture \& Life Sciences, Chungnam National University, 99 Daehak-ro, Yuseong-gu, Daejeon, Korea

* Corresponding author (E-mail: bjpark@cnu.ac.kr)
}

Fisheries of Japan created the term 'forest bathing' which is defined as making contacts with the forest or taking in its atmosphere, and this serves as a way to achieve individual's state of physical and mental relaxation (Park et al., 2010). Furthermore, it was observed that phytoncide reduced sympathetic responsiveness under restraint stress, highlighting benefits of phytoncide in prevention of stress-induced hypertension (Kawakami et al., 2004). Forest environment encouraged activity of human natural killer (NK) cell, percentage of NK cells and intracellular anti-cancer proteins in lymphocytes, and this increased NK activity lasted for more than a week in both male and female subjects after several stays in forests (Li et al., 2009). Therefore, physiological and psychological studies on forest healing environments have increased. In regard to this, temple forests, a significant ecological and scenic resource has been receiving great attention. Temple Forest in Korea can be defined as "a forest possessed by Buddhist temple for the purpose of landscape preservation and procurement of material and operating expenses for Buddhist temple." Temple forest takes up 1.3\% (83,000 ha) of the entire Korean forest with well-preserved natural ecology. Moreover, the landscape is in good condition and well-preserved due to Buddhist view of the world and its symbolism. In recent years, temple forest in Korea serves as a way of meditation and healing space for people through activities including temple-stay and ecological education.

The purpose of this study is to evaluate the possibility of temple forests in Korea as a healing environmental space in order to meet the social demand for a natural space for physical and mental stability. There have been some economic difficulties in measurement and analysis 
of NVOC which is one of the forests healing factor, including analysis expenses, specimen and other technical problems such as different concentration value depends on analysist or measurer's skill. Thus, the investigation has taken place with the intention to draw an effective estimation of change in concentration of NVOC in the microclimate environment by looking at Seonunsa temple forest in Korea as a research object, where Camellia japonica L., an evergreen broadleaved tree, is widely dispersed.

\section{MATERIALS AND METHODS}

\section{Study site}

Seonunsa Camellia japonica forest, Mountain Seonun Provincial Park in Korea

The study site is a temple forest located in seonunsa Camellia japonica forest, a mountain seonun Provincial Park (35²9' 37.2” N, $126^{\circ} 34^{\prime}$ 43.9” E, 16.5 ha), Korea. The temple forest was located in grand rocks which brings its beautiful scenery. The temple was founded in A.D.577, 24th year of King Weeduk, baekje Dynasty. The Camellia japonica forest, which has been officially designated by Korean natural memorial, is legally preserved by the government. Major characteristics of C. japonica are thick leaves, high water content and ignition resistance, so it was used to form as fire break forest to protect temples in the past. Nowadays, it receives great attention as a space of natural education and landscape preservation besides forest's primary functions in Korea. This study focuses on measurements of C. japonica forest that are known to have various therapeutic effects including meditation and healing space (Akihisa et al., 1997; Park et al., 2002; Jung et al., 2007). The vegetation status of surveyed stand is shown in Table 1.

\section{Measurement factors}

NVOC

Volatile organic compounds (VOC) are either liquid or gaseous organic compounds that have boiling points below $100^{\circ} \mathrm{C}$ and are easily evaporated into the atmosphere. The study concentrated on methods for analyzing NVOC. Majority of NVOC emitted in forests are generated by trees. Medical studies researching the effects of NVOC and how to cope with the diseases they cause have been published internationally (Yatagai et al., 1995; Trapp et al., 2001; Tani et al., 2002; Wang et al., 2006; Tani and Kawawata, 2008; Yang et al., 2011; Wang et al., 2012). Terpene compounds, a type of NVOC emitted by trees, are produced from multiple base units of isoprene, which contains five carbon and eight hydrogen atoms. Terpenoids, a common and large NVOC group, comprise hemiterpenes, monoterpenes and sesquiterpenes. Emission inventories show that isoprene and monoterpenes are the most prominent compounds. These compounds are usually strong smelling, rarely water soluble and found in plants, in animals and microorganisms (Kesselmeier and Staudt, 1999). In the study, 25 species of monoterpenes and sesquiterpenes (99\%, SigmaAldrich, USA) including $\alpha$-pinene, $\beta$-pinene and cam- phene were selected for the analysis. There are few tests to confirm the results of both the analysis device and the procedures. First, this study used 25 species of standard materials such as $\alpha$-pinene and $\beta$-pinene to obtain the calibration curve. Using the calibration curve to calculate each element's mass number and the square of its rate of diluting standard materials, it was found out that the majority of the materials has a linearity greater than 0.997 , e.g., $\alpha$-pinene $\left(R^{2}=0.997\right), \beta$-pinene $\left(R^{2}=\right.$ $0.998)$ and d-limonene $\left(R^{2}=0.999\right)$. The experiments using these materials also have a high reproducibility with respect to the coefficient of determination, which is suitable for the analysis.

\section{Microclimate Environment}

Concentration of NVOC changes depends on interaction of inner factors: genetic factor and biochemical factor and outer factors: biological factors of animals, plants and microorganism and non-biological factors including temperature, sunlight, relative humidity and wind velocity (Monson et al., 1994; Peñuelas and Joan, 2003; Niinemets et al., 2004; Baghi et al., 2012). The concentration appears to be changing by species of tree and microclimate. NVOC's concentration and its emitted mechanism are correlated by various factors which may lead to inadequate outcomes with accurate mechanism. Thus, the research aims to investigate the relationship between NVOC's concentration occurred in C. japonica forest (an evergreen broad-leave tree representing warm-temperate forest) by focusing on one of the mechanism factors, microclimate.

\section{Vegetation survey}

In order to study the geographic conditions of the subjects, we studied their aspect, altitude and slope using GIS (Fig 1) and used the quadrat method to study vegetation. The research object is located at an elevation of $240 \mathrm{~m}$ with an average slop grade greater than $15^{\circ}$ which is a falling slop. Its sedimentary form is creep and forest soil is brown forest soil. There was no state of erosion and the forest has high humidity, less wind exposure and its aspect are southeast from mountain valley. A $20 \mathrm{~m} \times 20 \mathrm{~m}$ quadrant was established at the NVOC measurement site, and plant species were divided into three categories which are tree layer, subtree layer and shrub layer to conduct a plant sociological survey. Records of the average tree height and crown projection charts of the tree layer were prepared. A log-wood survey of the tree species measuring $\geq 2 \mathrm{~cm}$ in diameter at breast height $(\mathrm{DBH})$ in the study site was performed. Temple forest, the research area covered with arborescent $C$ japonica L. which is approximately $6 \mathrm{~m}$ high and $14 \mathrm{~cm}$ of diameter of breast height. While the origin of inflow of C. japonica remains unclear, it has been developed and maintained with continuous management and preservation efforts since its settlement. It is observed that the species consisting vegetation are 34 families, 34 geneses, 37 species. The area is also covered with various types of evergreen plants such as Camellia sinesis L., Hedera rhombea (Miq.) Siebold \& Zucc. ex 
Table 1. Vegetation Status of Seonunsa Camellia japonica forest

\begin{tabular}{|c|c|c|c|c|c|}
\hline Scientific name & Family & Life form & red list & rare plant & $\begin{array}{l}\text { regional } \\
\text { species }\end{array}$ \\
\hline Ampelopsis heterophylla & Vitaceae & $\mathrm{N}$ & & & \\
\hline Asplenium incisum & Aspleniaceae & $\mathrm{H}$ & & & \\
\hline Athyrium niponicum & Aspleniaceae & G & & & \\
\hline Boehmeria spicata & Uriticaceae & Ch & & & \\
\hline Camellia japonica & Theaceae & M & & & I \\
\hline Humulus japonicas & Cannabaceae & Th & & & \\
\hline Celtis sinensis & Ulmaceae & MM & & & \\
\hline Cocculus trilobus & Menispermaceae & $\mathrm{N}$ & & & \\
\hline Commelina communis & Commelinaceae & Th & & & \\
\hline Corydalis incisa & Fumariaceae & Th & & & \\
\hline Cyrtomium fortunei & Dryopteridaceae & $\mathrm{H}$ & & & $\mathrm{I}$ \\
\hline Dioscorea japonica & Dioscoreaceae & G & & & \\
\hline Dioscorea septemloba & Dioscoreaceae & G & & & \\
\hline Gynostemma pentaphyllum & Cucurbitaceae & $\mathrm{H}$ & & & $\mathrm{I}$ \\
\hline Hedera rhombea & Araliaceae & MM & & & I \\
\hline Liriope platyphylla & Liliaceae & G & & & \\
\hline Millettia japonica & Leguminosae & $\mathrm{M}$ & $\mathrm{LC}$ & $\mathrm{VU}$ & $\mathrm{V}$ \\
\hline Nanocnide japonica & Urticaceae & $\mathrm{H}$ & & & I \\
\hline Ophiopogon japonicas & Liliaceae & G & & & \\
\hline Oplismenus undulatifolius & Gramineae & $\mathrm{H}$ & & & \\
\hline Orixa japonica & Rutaceae & $\mathrm{M}$ & & & $\mathrm{I}$ \\
\hline Osmorhiza aristata & Umbelliferae & G & & & \\
\hline Oxalis corniculata & Oxalidaceae & $\mathrm{Ch}$ & & & \\
\hline Paederia scandens var. scandens & Rubiaceae & $\mathrm{Ch}$ & & & \\
\hline Persicaria filiformis & Polygonaceae & $\mathrm{G}$ & & & \\
\hline Persicaria senticosa & Polygonaceae & Th & & & \\
\hline Phaenosperma globose & Gramineae & $\mathrm{H}$ & & & III \\
\hline Phryma leptostachya var. asiatica & Phrymaceae & G & & & \\
\hline Phytolacca americana & Phytolaccaceae & G & & & \\
\hline Plantago asiatica & Plantaginaceae & $\mathrm{H}$ & & & \\
\hline Sanicula chinensis & Umbelliferae & Th & & & \\
\hline Sasa borealis & Gramineae & $\mathrm{N}$ & & & \\
\hline Smilax sieboldii & Liliaceae & $\mathrm{N}$ & & & \\
\hline Solanum lyratum & Solanaceae & $\mathrm{Ch}$ & & & \\
\hline Trachelospermum asiaticum & Apocynaceae & M & & & \\
\hline Viola albida var. chaerophylloides & Violaceae & $\mathrm{H}$ & & & \\
\hline Zingiber mioga & Zingiberaceae & G & & & \\
\hline
\end{tabular}

Life form: Th: therophyes, G: geophytes, H: hemicryptophytes, Ch: chamaephytes, N: nanophanerophytes, M: micropanerophytes, MM: megaphanerophytes.

Red list: LC (least concerned species for IUCN).

Rare plant: VU (vulnerable plant species for Korean Forest Service and Korea National Arboretum, 2008).

Floristics special plants: Hierarchical degree $(\mathrm{V} \sim \mathrm{I})$ following distribution range: $\mathrm{V}$ (taxa distributed isolating or discontinuous), I (taxa distributed at least three subprovinces) (Ministry of Environment Republic of Korea, 2006)

Bean, Trachelospermum asiaticum (Siebold \& Zucc.) Nakai and Euonymus fortune var. radicans (Siebold \& Miq.) Rehder. Vegetation structure of $C$. japonica L. in the area forms a pure forest, Hedera rhombea (Miq.) Siebold \& Zucc. ex Bean, Camellia sinensis L., Liriop platyphylla F. T. Wang \& T. Tang are also prevalent in the area with high cover degree. Gochang county in north jeolla province, Korea where seonunsa is located $\left(35^{\circ} 30^{\prime} \mathrm{N}\right)$ is one of the northernmost regions where $C$. japonica is distributed. Vegetation of adjacent areas is consisted of summer green forest meanwhile seonunsa C. japonica forest forms evergreen forests types and generates the region's own vegetation landscape. It also controls microclimate of understory crown which supports advancement of local creatures and warm-temperate plant through the development of vegetation ever- 


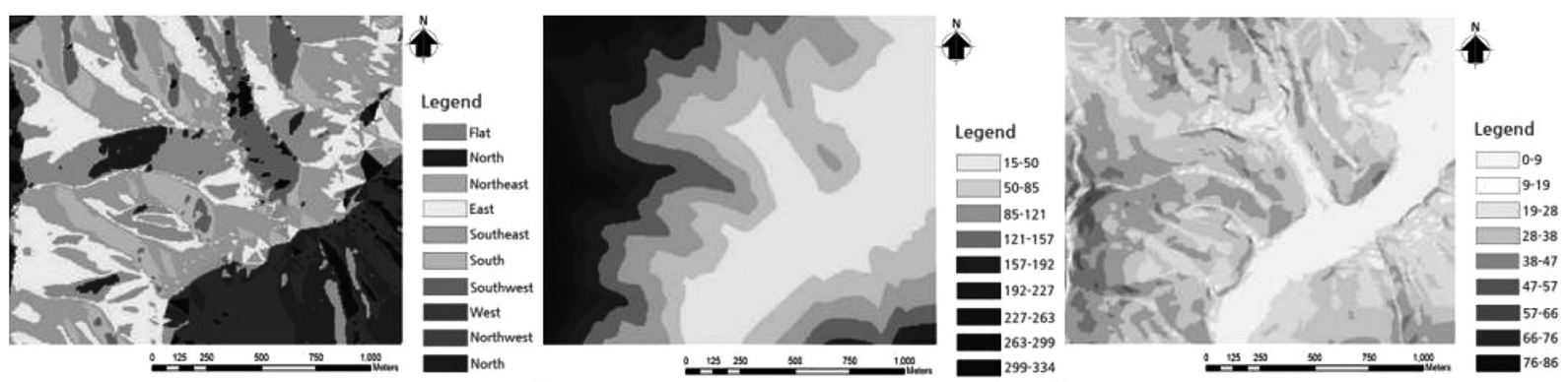

Fig. 1. The classification map of the surveyed area types.

green forest physiognomy with constant progress during winter time (Box and Fujiwara, 2014).

\section{Measurement methods} NVOCs

The adsorption tube method was used to collect samples. Tubes (Makers, USA) filled with Tenax TA (150 mg) and Carbotrap 2B were used for adsorption. The sample capture device was a mini pump (MP- $-30 \mathrm{KN}$, SIBATA, Japan) and the calibration was proceeded by a calculation of the adsorption error prior to the use of the flow meter. A total $9 \mathrm{~L}$ of NVOC volume was collected at a flow rate of $150 \mathrm{~mL} / \mathrm{min}$. The sampling equipment was installed on a tripod, $1.5 \mathrm{~m}$ from the ground, and the average value was calculated through duplicate sampling at every location. Disposable polyethylene gloves and antibacterial masks were used to prevent artificial errors when in contact with the tube during the installation. After sampling, the sample tubes were maintained at a temperature below $4^{\circ} \mathrm{C}$ and analyzed within $48 \mathrm{~h}$. The samples were subjected to qualitative and quantitative analyses using a gas chromatography-mass spectrometer (7890N-5975, Agilent, USA) with a thermal desorption system (GC-MSD, Gerstel TDS, Gerstel, Germany). The substances adsorbed by the adsorption tube were concentrated in a low-temperature cryofocusing device, which intakes high-purity helium gas at a velocity of $1 \mathrm{~mL} / \mathrm{min}$ from a thermal desorption device. The device desorbed the gas for 3 minutes at $210^{\circ} \mathrm{C}$ and maintained its temperature at $-30^{\circ} \mathrm{C}$. The substances were then subjected to thermal desorption for 3 minutes at $220^{\circ} \mathrm{C}$, infused into a GC spectrometer and detected using an MSD.

\section{Microclimate}

The direction and slope of the site were measured in terms of locational environment. A setup was designed to ensure that a portable multifunction meter (Poly MI 6401, METREL, Slovenia) recorded the physical features of the site environment (temperature, humidity, wind velocity, dew point, globe temperature, air current and wet-bulb globe temperature) at intervals of 1 minute. The meter was installed at a height of $1.5 \mathrm{~m}$ in equilibrium on a tripod approximately $1 \mathrm{~m}$ from a mini pump and digitalized measurement results were saved and then converted for the analysis. The results were analyzed using the Sensor Link Pro program (METREL,
Slovenia). The data was saved 5 minutes before and after each measurement were excluded from the analysis to minimize measurement errors.

\section{Data Analysis}

The data were analyzed for total of 52. However, 4 samples were excluded from the analysis because they that were detected as high concentration by unspecific factors were considered as robustness. All statistical analyses were performed using Statistical Package for Social Science software, Version 23 (IBM Corp., SPSS Inc., NY, USA). In this study, Pearson's correlation coefficient was used as a main correlation analysis because it is most commonly used to statistically measure the level of correlation among the variables. Among the regression analysis, stepwise regression analysis method was used because it only contains the variables that are able to affect dependent variable into the equation. In order to certify the multiple regression model's significance, VIF coefficient was used to check multicollinearity.

\section{RESULTS}

\section{Characteristics of NVOC at Camellia japonica for- est}

The comparison of the NVOC construction in Camellia japonica forest in summer showed $51 \%$ of $\alpha-$ pinene $\left(1.79 \mu \mathrm{g} / \mathrm{m}^{3}\right)$ followed by $19 \%$ of $\beta$-pinene $\left(0.68 \mu \mathrm{g} / \mathrm{m}^{3}\right)$, as shown in Table 2 . The other majority NVOC emitted camphene $\left(0.19 \mu \mathrm{g} / \mathrm{m}^{3}\right)$, camphor $\left(0.16 \mu \mathrm{g} / \mathrm{m}^{3}\right), \quad \mathrm{d}$-limonene $\quad\left(0.12 \mu \mathrm{g} / \mathrm{m}^{3}\right), \quad \delta$-3-carene $\left(0.05 \mu \mathrm{g} / \mathrm{m}^{3}\right), \quad \gamma$-terpinene $\quad\left(0.04 \mu \mathrm{g} / \mathrm{m}^{3}\right), \quad$ p-cymene $\left(0.04 \mu \mathrm{g} / \mathrm{m}^{3}\right)$, eucalyptol $\left(0.04 \mu \mathrm{g} / \mathrm{m}^{3}\right), \quad \alpha$-terpinene $\left(0.03 \mu \mathrm{g} / \mathrm{m}^{3}\right)$, myrcene $\left(0.02 \mu \mathrm{g} / \mathrm{m}^{3}\right)$, bornyl acetate $\left(0.02 \mu \mathrm{g} / \mathrm{m}^{3}\right)$, terpinolene $\left(0.02 \mu \mathrm{g} / \mathrm{m}^{3}\right)$, linalool $(0.01 \mu \mathrm{g} /$ $\left.\mathrm{m}^{3}\right)$, cedrol $\left(0.003 \mu \mathrm{g} / \mathrm{m}^{3}\right)$ and $\alpha$-humulene $(0.002 \mu \mathrm{g} /$ $\mathrm{m}^{3}$ ). Comparative analysis on TNVOC (Total NVOC) concentration of emitted various tree species showed Pinus densiflora $\left(14.21 \mu \mathrm{g} / \mathrm{m}^{3}\right)$, Abies holophylla $\left(4.66 \mu \mathrm{g} / \mathrm{m}^{3}\right)$, Pinus koraiensis $\left(4.31 \mu \mathrm{g} / \mathrm{m}^{3}\right)$, Camellia japonica $\left(3.71 \mu \mathrm{g} / \mathrm{m}^{3}\right), \quad$ Chamaecyparis obtusa $\left(1.92 \mu \mathrm{g} / \mathrm{m}^{3}\right), \quad$ Larix kaempferi $\quad\left(1.12 \mu \mathrm{g} / \mathrm{m}^{3}\right)$, Cinnamomum camphora $\left(0.55 \mu \mathrm{g} / \mathrm{m}^{3}\right)$, Machilus thunbergii $\left(0.40 \mu \mathrm{g} / \mathrm{m}^{3}\right)$, as shown in Fig. 2. C. japon$i c a \mathrm{~L}$. is included in the tea family, one of the representative species of evergreen broad-leaved trees and widely spread in warm-temperate zones. Therefore, C. japon- 
Table 2. The characteristics of concentration of NVOCs component in Camellia japonica forest

\begin{tabular}{cccc}
\hline Structure Material & $\begin{array}{c}\text { Concentration } \\
\left(\mu \mathrm{g} / \mathrm{m}^{3}\right)\end{array}$ & Structure Material & $\begin{array}{c}\text { Concentration } \\
\left(\mu \mathrm{g} / \mathrm{m}^{3}\right)\end{array}$ \\
\hline \hline$\alpha$-pinene & 1.79 & $\delta$-3-carene & 0.05 \\
camphene & 0.19 & p-cymene & 0.04 \\
$\beta$-pinene & 0.68 & myrcene & 0.02 \\
sabinene & 0.29 & cedrol & 0.003 \\
$\alpha$-terpinene & 0.03 & camphor & 0.16 \\
limonene & 0.12 & linalool & 0.01 \\
eucalyptol & 0.04 & bornyl acetate & 0.02 \\
$\gamma$-terpinene & 0.04 & $\alpha$-humulene & 0.002 \\
terpinolene & 0.02 & - & - \\
\hline
\end{tabular}

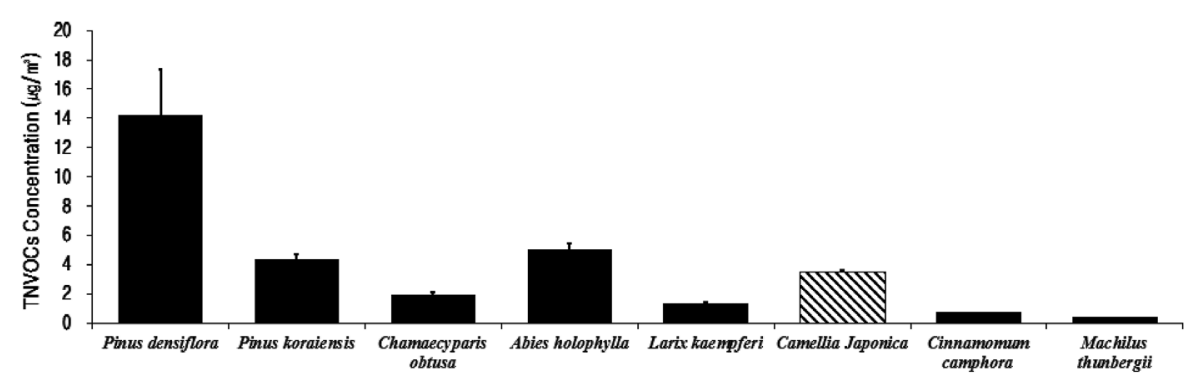

Fig. 2. The variations of TNVOCs at the surveyed area.

ica forest is considered as more possible healing space as concentration of phytoncide is higher compared to coniferous forests such as A. holophylla, P. koraiensis and $C$. obtuse.

\section{The intraday variation of NVOCs concentration at Camellia japonica forest}

To evaluate the changes in NVOC concentration dur- ing the day in C. japonica forest, NVOC were measured three times (sunrise, culmination and sunset) at each point of the study site. Four study sites were set up at $50 \mathrm{~m}$ intervals according to the geographical characteristics in the shape of a ' $L$ '. The NVOC concentration detected from C. japonica increased over time from the sunrise to sunset (Fig. 3). Nineteen substances in total including $\alpha$-pinene and $\beta$-pinene were detected in

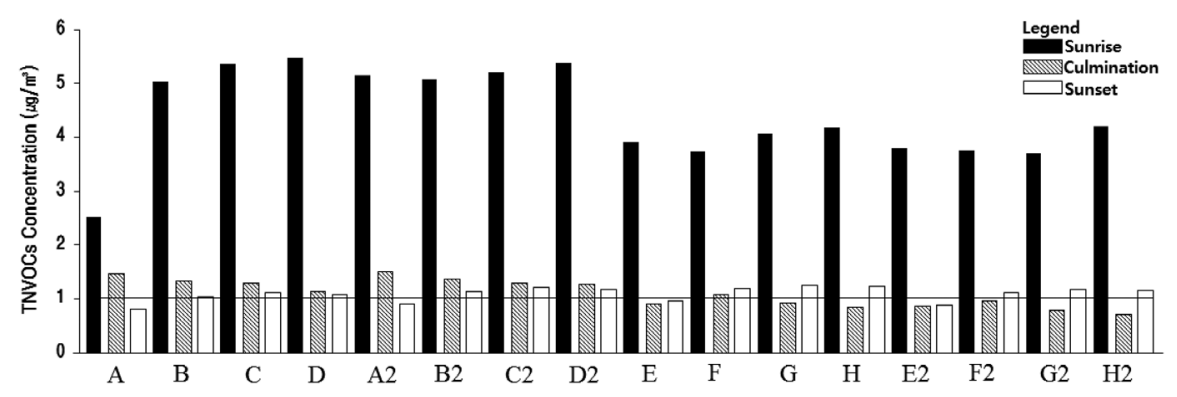

Fig. 3. The variations of TNVOCs at Camellia japonica forest.

A, B, C, D: results of primary measuring areas.

A2, B2, C2, D2: the day after's measuring results of primary measuring areas.

$\mathrm{E}, \mathrm{F}, \mathrm{G}, \mathrm{H}$ : results of additional measuring areas.

E2, F2, G2, H2: the day after's measuring results of additional measuring areas.

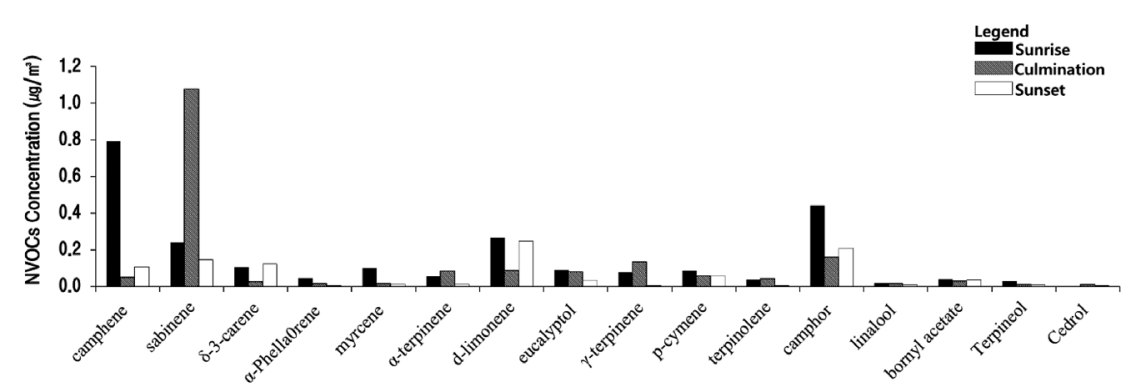

Fig. 4. Intraday record of concentration of NVOCs. 
which $\alpha$-pinene and $\beta$-pinene were detected at high concentrations during the sunrise. Thus, based on a thorough investigation on other substances that were detected at low concentration, it was confirmed that sabinene, $\gamma$-terpinene etc. were detected at high concentrations during culmination (Fig. 4). Therefore, reactivity to the photo-environment was considered as low.

\section{Relationship between NVOCs and microclimate at Camellia japonica forest}

To maintain the accuracy of the measured values, data taken from the first 5 minutes of each measurement were excluded. As a result, a negative linear relationship was confirmed between NVOC and wind velocity where wind velocity decreased with increasing in concentration of NVOC (Fig. 5). A positive linear relationship was confirmed with the temperature and humidity, showing that they increased with increasing in concentration of NVOC (Fig. 6 and 7). Microclimates and materials showing abnormal values in correlation analysis were excluded, and the excluded factors were analyzed, followed by reanalysis.

\section{Prediction model for NVOCs concentration in Camellia japonica forest}

This study conducted a multiple regression analysis to create NVOC concentration prediction model for changes in microclimate environment (Table 3). To verify the independence of the residuals, the durbin-watson values were evaluated; a value of 1.748 was obtained which shows no autocorrelation. The variance inflation factor (VIF) in this study was 3.681-5.013 and it indicates no multicollinearity issues. The results of the study site analysis presented a significant regression model with an $F$ value of 80.169. The $R^{2}$ was as high as $84.5 \%$, confirming that the regression model of the concentration prediction of NVOC in C. japonica forest has significant explanatory power. Analysis of variance (ANOVA) showed a significantly high $P$ value of 0.000 and the explanatory power of the regression model equation was high. For temperature, the value of $B$ was 0.394 and the test statistic was confirmed to have a significant effect with a $t$ value of 4.599 and significance probability of 0.000 . Due to the fact that the standardized beta value is 0.610 , the concentration of NVOC increased by 0.610 (61.0\%) when the temperature increased by $1^{\circ} \mathrm{C}$. In further analysis, the value of $B$ was analyzed as -0.002 and the test statistic was confirmed to have a significant negative effect with a $t$ value of -3.429 and significant probability of $P$ of 0.001 . Because of the standardized beta value of -0.390 , the concentration of NVOC decreased by -0.390 (39.0\%) when illuminance increased by $1 \%$. For wind velocity, the value of $B$ was -0.602 and the test statistic showed that the $t$ value was -2.781 and significance probability was 0.008 which is significant. Because the standardized beta value was -0.365 , the concentration of NVOC decreased by -0.365 (36.5\%) when wind speed increased by $1 \%$. In order to predict concentration of NVOC in the C. japonica for-

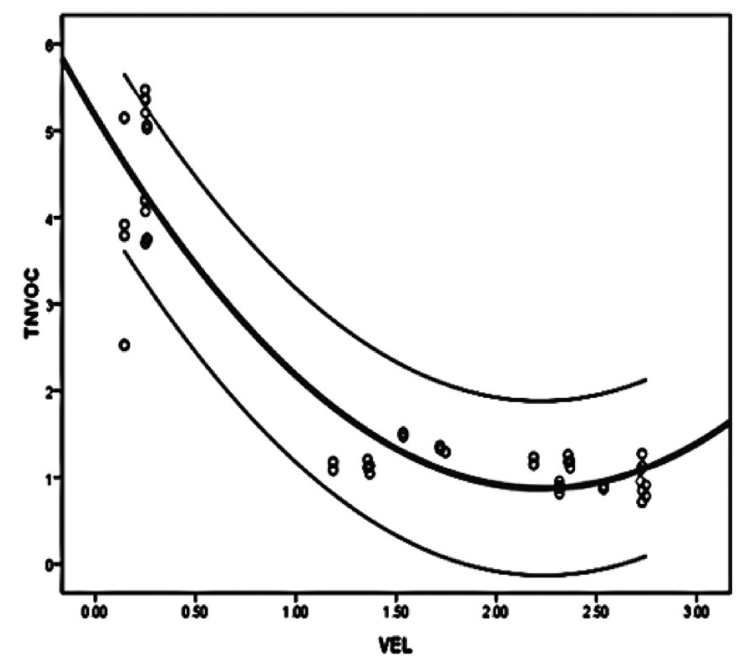

Fig. 5. The Correlation between NVOCs concentration and wind velocity in Camellia japonica forest.

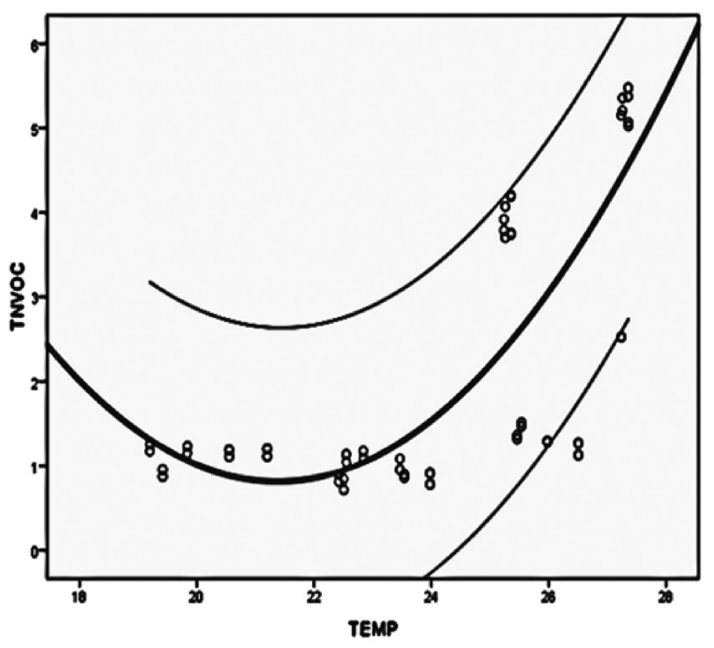

Fig. 6. The Correlation between NVOCs concentration and temperature in Camellia japonica forest.

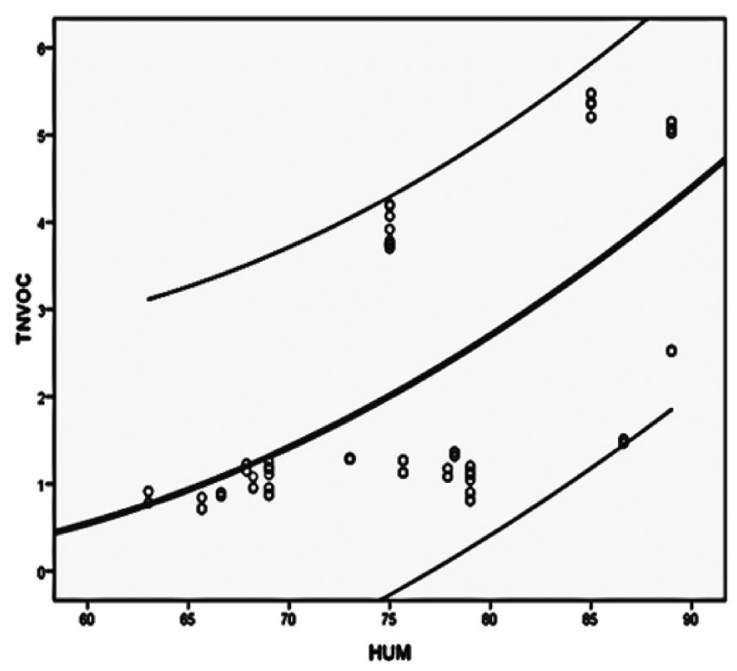

Fig. 7. The Correlation between NVOCs concentration and humidity in Camellia japonica forest 
Table 3. Result of multiple regression analysis for Camellia japonica forest

\begin{tabular}{cccccccr}
\hline Variables & SD & Beta & $t$ & VIF & $R^{2}$ & $F$ & D-W \\
\hline \hline Constant & 2.187 & & -2.607 & & & & \\
Vel & .217 & -.365 & -2.781 & 4.904 & & 80.869 & 1.748 \\
Temp & .086 & .610 & 4.599 & 5.013 & .845 & $(.000)$ & \\
Illm & .001 & -.390 & -3.429 & 3.681 & & & \\
\hline
\end{tabular}

Vel: Wind velocity, Temp: Temperature, Illm: Illumination.

est, independent variables influencing the concentration were selected from the microclimate by correlation analysis, followed by multiple regression analysis to create the following equation model:

$$
\begin{aligned}
\mathrm{MNCF}= & -5.7+0.394 \times \mathrm{TEMP}-0.602 \times \\
& \mathrm{VEL}-0.002 \times \mathrm{IllM}
\end{aligned}
$$

Where, MNCF = Model of NVOC concentrations from $C$. japonica forest, TEMP = temperature, VEL = wind velocity and IllM = illumination. However, this prediction model was confined within narrow microclimate range limits.

\section{DISCUSSION}

To achieve sustainable development of temple forests, this study was conducted to evaluate scientifically potential of these forests as a healing space with cultural value. Temple forest in Korea serves as a way of meditation and healing space for people. Additionally, the significance of warm temperate forest environment due to climate change was analyzed. To complement economic and technical issues of existing NVOC measurement techniques, the study conducted a total of 52 survey and analysis in a Camellia japonica forest. Analysis of the NVOC emitted at the study site showed that 19 types of substances were detected. The comparison of the NVOC construction in $C$. japonica forest showed $51 \%$ of $\alpha-$ pinene $\left(1.79 \mu \mathrm{g} / \mathrm{m}^{3}\right)$, followed by $19 \%$ of $\beta$-pinene $\left(0.68 \mu \mathrm{g} / \mathrm{m}^{3}\right), 8 \%$ of sabinene $\left(0.29 \mu \mathrm{g} / \mathrm{m}^{3}\right)$. Higher ratio of $\alpha$-pinene is known for effective reduction and resistance on stress, microbial, oxidant, cancer, depressant, insecticidal (Juven et al., 1994; Gustafson et al., 1998; Cox et al., 2000; Lambert et al., 2001; EH et al., 2003; McKay et al., 2003; Kawakami et al., 2004; Yamaoka et al., 2005; Mercier et al., 2009; Lima et al., 2010; Menezes et al., 2010; Matsuo et al., 2011; Lee et al.,2012; Mishra et al., 2012; Wang et al., 2012). $\beta$-pinene was known for effective reduction in the hypotension, tachycardia (Gavrilov et al., 2010; Menezes et al., 2010). Some compositions differed from those in previous coniferous forest studies (Kim et al., 2013; 2014; 2015). This may affect chemical characteristics of the Camellia japonica NVOC and have species effects. Intra-day measurement of changes in NVOC concentrations found out that concentrations were higher after the sunset, when the boundary layer of the atmosphere contracted, stabilized and the photo-environment changed. This is consistent with the result showing that the atmosphere is stable and not mixed well in night time compared to during the day time when it is perished by rapid reactions with oxidants such as $\mathrm{O}_{3}$ in the atmosphere, although there may have be some differences in concentration changes between the atmosphere in forests and the air above the canopy (Harrison et al., 2001, Cerqueira et al., 2003). In addition, NVOC concentrations increased when photoenvironment changed and wind velocity was less affected. Among the detected substances, sabinene, camphor and myrcene were highly concentrated during culmination, and thus showing lower reactivity with the photo-environment than other substances. The correlation between NVOC concentration and microclimate demonstrates that higher temperature and humidity were associated with a higher NVOC concentration whereas higher wind velocity resulted in a lower concentration. In this study, a prediction model for NVOC concentration of $C$. japonica was proposed considering the concentration changes related to the microclimate, and regression analysis showed an explanatory power as high as $84.5 \%$. Domestic wild C. japonica L. is generally odorless and used in daily life as extruded oil of seeds and petals. However, it emits a relatively high concentration of NVOC and therefore, additional studies are required to analyze these emitted NVOC. Our data provides a foundation for developing forest healing programs in temple forests. However, this study has some experimental limits. For example, the model is only able to predict the concentration in certain microclimate conditions. First, pure forests are more widely spread out than mixed forests are in Korea. Also, uneven-aged forests have more complicated composition than do evenaged forests, so it is needed to develop a new concentration models of NVOC based on various criteria. Second, because the mechanism factors of occurrence interact each other, it is needed to check the correlation between the various internal and external factors like biomass, leaf area, flowering, PAR, soil, stand age, density of standing trees, evapotranspiration. Third, it is needed to monitor seasonal NVOC concentrations for each forest floor because this study monitored other research sites only for spring and summer. Lastly, NVOC study can result in various conclusions depending on the operators. The measuring processes for NVOC concentration in Korea are mostly on the basis of indoor air quality processes without specific guidelines. Therefore, it is necessary to set up a standard process through the feed- 
backs from the experts for air or forest analysis. This study developed a model to effectively predict NVOC concentration. We hope that the model will be used to predict NVOC concentration in sites that are managed as 'Buddhist temple Forests', and thus contribute to wellbeing of public.

\section{AUTHOR CONTRIBUTIONS}

G. Kim carried out the field experiment of the research and wrote the statistical analysis and the manuscript. B. J. Park co-designed the experiment and performed the field experiment. S. Koga conceived the experiment, participated in its design, coordination and tree species identification and helped to draft the manuscript. All authorities assisted in editing of the manuscript and approved the final version.

\section{ACKNOWLEDGEMENTS}

This study was conducted in collaboration with the Kyushu University Forests in Japan. The authors thank Professor Kyoichi OTSUKI of Kyushu University Forests for valuable discussions and extensive help with the field experiment. We would also like to show our gratitude to the Seonunsa for providing the research location during the course of the research. The research has been documented based on collaborative opinions of various researchers, not the official opinion of National Institutes of Forest Research in Korea.

\section{REFERENCES}

Akihisa, T., K. Yasukawa, Y. Kimura, S. I. Takase, S. Yamanouchi and T. Tamura 1997 Triterpene alcohols from camellia and sasanqua oils and their anti-inflammatory effects. Chem. Pharm. Bull., 45(12): 2016-2023

Baghi, R., D. Helmig, A. Guenther, T. Duhl and R. Daly 2012 Contribution of flowering trees to urban atmospheric biogenic volatile organic compound emissions. Biogeosciences, $\mathbf{9}(10)$ : 3777

Box, E. O. and K. Fujiwara 2014 Warm-Temperate deciduous forests around the Northern Hemisphere. Springer, London New York, pp. 1-80

Cerqueira, M. A., C. A. Pio, P. A. Gomes, J. S. Matos and T. V. Nunes 2003 Volatile organic compounds in rural atmospheres of central Portugal. Sci. Environ., 313(1): 49-60

Cox, S. D., C. M. Mann, J. L. Markham, H. C. Bell, J. E. Gustafson, J. R. Warmington and S. G. Wyllie 2000 The mode of antimicrobial action of the essential oil of Melaleuca alternifolia (tea tree oil). J. Appl. Microbiol., 88(1): 170-175

Cultural Heritage Administration 2008 A survey report on natural monument in forest area. pp. 16-19

Eh, E. K., M. F. Al-Ajmi and A. M. Al-Bekairi 2003 Some Cardiovascular Effects of The Dethymoquinonated Nigella Sativa Volatile oil and its Major Components $\alpha$-pinene and $\mathrm{p}$ cymene in rats. Saudi Pharm. J., 11(3): 104-110

Gavrilov, V. V., V. A. Startseva, L. E. Nikitina, O. A. Lodochnikova, O. I. Gnezdilov, S.A. Lisovskaya, N. I. Glushko and E. N. Klimovitskii 2010 Synthesis and antifungal activity of sulfides, sulfoxides, and sulfones based on (1S) - $(-)-\beta$-pinene. Pharm. Chem. J., 44(3): 126-129

Gustafson, J. E., Y. C. Liew, S. Chew, J. Markham, H. C. Bell, S. G. Wyllie and J. R. Warmington 1998 Effects of tea tree oil on Escherichia coli. App. Microbiol., 26(3): 194-198
Harrison, D., M. C. Hunter, A. C. Lewis, P. W. Seakins, B. Bonsang, V. Gros, M. Kanakidou, M. Touaty, I. Kavouras, N. Mihalopoulos, E. Stephanou, C. Alves, T. Nunes, and C. Pio 2001 Ambient isoprene and monoterpene concentrations in Greek fir (Abies borisii-regis) forest. Reconciliation with emissions measurements and effects on measured $\mathrm{OH}$ concentrations. Atmos. Environ., 35(27): 4699-4711

Jung, E., J. Lee, J. Baek, K. Jung, J. Lee, S. Huh, S. Kim, J. Koh, D. Park (2007). Effect of Camellia japonica oil on human type I procollagen production and skin barrier function. $J$. Ethnopharmacol., 112(1): 127-131

Juven, B. J., J. Kanner, F. Schved and H. Weisslowicz 1994 Factors that interact with the antibacterial action of thyme essential oil and its active constituents. J. Bacteriol., $\mathbf{7 6}(6)$ : $626-631$

Kawakami, K., M. Kawamoto, M. Nomura, H. Otani, T. Nibika and T. Gonda 2004 Effects of phytoncides on blood pressure under restraint stress in SHRSP. Clin. Exp. Pharmacol. Physiol., 31(s2): S27-S28

Kesselmeier, J. and M. Staudt 1999 Biogenic volatile organic compounds (VOC): an overview on emission, physiology and ecology. J. Atmos. Chem., 33: 23-88

Kim, G., C. Kwon, H. Lim, D. Yeom, Y. Choi, D. Joung, H. Lim, H. Shin and B. J. Park 2013 Relationship between NVOC and Korean Red Pine (Pinus densiflora) Forest Environment in Winter Season. Ins. Fo. Rec. Wel., 17(4): 133-141

Kim, G., C. Kwon, H. Lim, D. Yeom, D. Joung, Y. Choi and B. J. Park 2014 Relationship between NVOC and korean red pine (Pinus densiflora) forest environment in spring season. J. Korean For. Soc., 103(3): 483-489

Kim, G., B. J. Park, D. Joung, D. G. Yeom and S. Koga 2015 Healing environments of major tree species in Kyushu University Forests: a case study. J. Fac. Agric. Kyushu Univ., 60(2): 477-483

Kim, G., B. J. Park, P. Yeon, S. Lee, D. Joung, C. Park and S. Koga 2016 Case study on the changes in the physical environment in forest healing spaces. J. Fac. Agric., Kyushu Univ., 61(2): 375-381

Korea National Arboretum 2009 Rare plants data book in Korea National Arboretum, Pocheon. pp. 1-310

Lambert, R. J. W., P. N. Skandamis, P. J. Coote and G. J. Nychas 2001 A study of the minimum inhibitory concentration and mode of action of oregano essential oil, thymol and carvacrol. $J$. Appl. Microbiol., 91(3): 453-162

Lee, H. F., T. S. Lee and Y. R. Kou 2012 Anti-inflammatory and neuroprotective effects of triptolide on traumatic brain injury in rats. Respir. Physiol. Neurobiol., 182(1): 1-8

Li, Q., M. Kobayashi, Y. Wakayama, H. Inagaki, M. Katsumata, Y. Hirata, K. Hirata, T. Shimizu, T. Kawada, B. J. Park, T. Ohira, T. Kagawa and Y. Miyazaki 2009 Effect of phytoncide from trees on human natural killer cell function. Int. J. Immu. Pharm., 22(4): 951-959

Lima, F. J., T. S. Brito, W. B. Freire, R. C. Costa, M. I. Linhares, F. C. Sousa, S. Lahlou, J. H. L. Cardoso, A. A. Santos and P. J. Magalhães 2010 The essential oil of Eucalyptus tereticornis, and its constituents $\alpha$-and $\beta$-pinene, potentiate acetylcholine-induced contractions in isolated rat trachea. Fitoterapia, 81(6): 649-655

Matsuo, A. L., C. R. Figueiredo, D. C. Arruda, F. V. Pereira, J. A. B. Scutti, M. H. Massaoka, L. R. Travassos, P. Sartorelli and J. H. Lago $2011 \quad \alpha$-Pinene isolated from Schinus terebinthifolius Raddi (Anacardiaceae) induces apoptosis and confers antimetastatic protection in a melanoma model. Biochem. Biophys. Res. Commun., 411(2): 449-454

McKay, S. A. B., W. L. Hunter, K. A. Godard, S. X. Wang and D. M. Martin 2003 Insect attack and wounding induce traumatic resin duct development and gene expression of (-)-pinene synthase in Sitka spruce. Plant. Physiol., 133(1): 368-378

Menezes, I. A., C. Bareeto, Â. R. Antoniolli, M. R. Santos and D. P. D. Sousa 2010 Hypotensive activity of terpenes found in essential oils. Z. Naturforch., C: Biosci., 65(10):562-566

Mercier, B., J. Prost and M. Prost 2009 The essential oil of tur- 
pentine and its major volatile fraction ( $\alpha$-and $\beta$-pinenes): a review. Int. J. Occup. Med. Environ. Health, 22(4): 331-342

Marin, M. F., C. Lord, J. Andrew, R. P. Juster, S. Sindi, G. Arsenault-Lapierre, A. J. Fiocco and S. J. Lupien 2011 Chronic stress, cognitive functioning and mental health. Neurobiol. Learn. Mem., 96: 583-595

Ministry of Environment Republic of Korea 2006 A guide to the third National Natural Environment Research. pp. 114-155 (in Korean)

Mishra, A. K., A. Mishra, A. Verma and P. Chattopadhyay 2012 Effects of calendula essential oil-based cream on biochemical parameters of skin of albino rats against ultraviolet $\mathrm{B}$ radiation. Sci. Pharm., 80(3): 669-684

Monson, R. K., P. C. Harley, M. E. Litvak, M. Wildermuth, A. Guenther, P. R. Zimmerman, and R. Fall 1994 Environmental and developmental controls over the seasonal pattern of isoprene emission from aspen leaves. Oecologia, 99(3): 260-270

Niinemets, Ü., F. Loreto and M. Reichstein 2004 Physiological and physicochemical controls on foliar volatile organic compound emissions. Trends plant sci., 9(4): 180-186

Park, J., J. Hur, J. Park, T. Hatano, T. Yoshida, H. Miyashiro, B. Min and M. Hattori 2002 Inhibitory effects of Korean medicinal plants and camelliatannin $\mathrm{H}$ from Camellia japonica on human immunodeficiency virus type 1 protease. Phytother Res. 2002 Aug; 16(5): 422-6

Park, B. J., Y. Tsunetsugu, T. Kasetani, T. Kagawa and Y. Miyazaki 2010 The physiological effects of Shinrin-yoku (taking in the forest atmosphere or forest bathing): evidence from field experiments in 24 forests across Japan. Environ health medi, 15(1): $18-26$

Peñuelas, J. and L. Joan 2003 BVOCs: plant defense against climate warming?. Trends plant sci., 8(3): 105-109

Slater, S. J., Christiana, R. W. and J. Gustat 2020 Recommendations for Keeping Parks and Green Space Accessible for Mental and Physical Health During COVID-19 and Other Pandemics. Prev. chronic dis., 17: E59

Stanhope, J., M. F. Breed and P. Weinstein 2020 Exposure to greenspaces could reduce the high global burden of pain. Environ. Res., 187: 109641

Tafet, G. E. and R. Bernardini 2003 Psychoneuroenendocrinological links between chronic stress and depression. Prog. Neuropsychopharmacol. Biol.
Psychiatry., 27(6): 893-903

Tani, A. and J. Kawawata 2008 Isoprene emission from the major native Quercus spp. in Japan. Atmos. Environ., 42(19): 45404550

Tani, A., S. Nozoe, M. Aoki and C.N. Hewitt 2002 Monoterpene fluxes measured above a Japanese red pine forest at Oshiba plateau, Japan. Atmos. Environ., 36: 3391-3402

Tollefson, J. 2020 Why deforestation and extinctions make pandemics more likely. Nature, $\mathbf{5 8 4}(7820)$ : 175-176

Trapp, D., K. M. Cooke, H. Fischer, B. Bonsang, R. U. Zitzelsberger, R. Seuwen, C. Schiller, T. Zenker, U. Parchatka, T. V. Nunes and C. A. Pio 2001 Isoprene and its degradation products methyl vinyl ketone, methacrolein, and formaldehyde in a eucalyptus. Chemosphere, 3: 295-307

Wang, S. Y., W. C. Lai, F. H. Chu, C. T. Lin, S. Y. Shen and S. T. Chang 2006 Essential oil from the leaves of cryptomeria japonica acts as a silverfish (Lepisma saccharina) repellent and insecticide. J. Wood. Sci., 52: 522-526

Wang, W., N. Li, M. Luo, Y. Zu and T. Efferth 2012 Antibacterial activity and anticancer activity of Rosmarinus officinalis L. essential oil compared to that of its main components. Molecules, 17: 2704-2713

World Health Organization 2015 World health organization global coordination mechanism on noncommunicable diseases. WHO press: Geneva, Switzerland, pp. 1-56

Yamaoka, S., T. Tomita, Y. Imaizumi, K. Watanabe and A. Hatanaka 2005 Effects of plant-derived odors on sleep-wakefulness and circadian rhythmicity in rats. Chem. Sense., 30 (suppl 1): i264265

Yang, Z., N. Wu, Y. Zu and Y. Fu 2011 Comparative anti-infectious bronchitis virus (IBV) activity of (-)-pinene: Effect on nucleocapsid (N) protein. Molecules, 16: 1044-1054

Yatagai, M., M. Ohira, T. Ohira and S. Nagai 1995 Seasonal variations of terpene emission from trees and influence of temperature, light, and contact stimulation on terpene emission. Chemosphere, $\mathbf{3 0}$ (6): 1137-1149

Zabini, F., L. Albanese, F. R. Becheri, G. Gavazzi, F. Giganti, F. Giovanelli, G. Gronchi, A. Guazzini, M. Laurino, Q. Li, T. Marzi, F. Mastorci, T. Meneguzzo, S. Righi and T. Marzi 2020 Comparative Study of the Restorative Effects of Forest and Urban Videos during Covid-19 Lockdown: Intrinsic and Benchmark Value. Preprints., 2020080707 